\title{
HUBUNGAN POTENSI INDRA, AKAL, DAN KALBU DALAM AL-QUR'AN MENURUT PARA MUFASSIR
}

\author{
Sawaluddin Siregar \\ STAIR Bagan Batu Rohil Riau \\ regarsawaluddin@gmail.com
}

Diterima 23-03-2020 | Direview 15-05-2020 | Diterbitkan 27-06-2020

\begin{abstract}
:
In the Qur'an the letter an-Nabl verse 78, Allah indicates that the potential (hearing, sight, and heart) that has been granted needs to be optimally and integratedly developed. Because with that potential he can learn from the environment, nature, and the community where he lives with the hope of becoming a complete adult human being. This research was designed in the form of library research or Library research that uses various sources of literature as a data source that relates to the thinking of a character who at a certain time, cultural conditions, the community at that time, along with documents, then the methodologically used approach is interpretation. Based on the explanations of the three potentials, they clearly appear to have a close relationship, and support each other, if one thing does not function properly, it will not produce a good response. Indra's potential, aql, and Kalbu have strong, inseparable relationships. The position of each potential and that drives the potential, resulting in the application of the effects of stimuli received by the senses which are then transfected into oak and the brain sends data to the heart and heart which integrates the case, resulting in action
\end{abstract}

Keywords: Potential Relationships of Indra, Intellect, and Kalbu in the AlQur'an According to Mufassir

\begin{abstract}
Abstrak
Dalam Alquran surat an-Nabl ayat 78, Allah menyatakan bahwa potensi (pendengaran, penglihatan, dan hati) yang telah diberikan perlu dikembangkan secara optimal dan terintegrasi. Karena dengan potensi tersebut ia dapat belajar dari lingkungan, alam, dan masyarakat tempat tinggalnya dengan harapan menjadi manusia dewasa yang utuh. Penelitian ini dirancang dalam bentuk studi pustaka atau studi pustaka yang menggunakan berbagai sumber literatur sebagai sumber data yang berkaitan dengan pemikiran seorang tokoh yang pada waktu tertentu, kondisi budaya, masyarakat pada saat itu, beserta dokumendokumennya, maka pendekatan yang digunakan secara metodologis adalab interpretasi. Berdasarkan penjelasan dari ketiga potensi tersebut jelas terlihat
\end{abstract}


memiliki hubungan yang erat, dan saling mendukung, apabila suatu hal tidak berfungsi dengan baik maka tidak akan menghasilkan respon yang baik. Potensi Indra, aql, dan kalbu memiliki relasi yang kuat dan tidak terpisabkan. Posisi masing-masing potensi dan yang mendorong potensi tersebut, menghasilkan penerapan efek rangsangan yang diterima oleh indera yang kemudian ditransfusikan menjadi pohon ek dan otak mengirimkan data ke jantung dan jantung yang menyatukan kasus tersebut, menghasilkean tindakan

Kata Kunci: Hubungan Potensi Indra, Akal, Dan Kalbu Dalam AlQur'an Menurut Para Mufassir

\section{Pendahuluan}

Pandangan Islam, manusia adalah makhluk Allah yang bertugas sebagai khalifah di bumi. Allah telah memberitahukan kepada para malaikat bahwa Dia akan menciptakan manusia yang diserahi tugas menjadi khalifah, sebagaimana yang tersurat dalam al-Qur'an surat al-Baqarah ayat 30. Di samping manusia sebagai khalifah, mereka juga termasuk makhluk pedagogik yaitu makhluk Allah yang dilahirkan membawa potensi dapat dididik dan mendidik sebagaimana dalam Al-Qur'an surat an-Nahl ayat 78. Dalam alQur'an surat an-Nahl ayat 78, Allah mengisyaratkan bahwa potensi (pendengaran, penglihatan, dan hati) yang telah dianugerahkan tersebut perlu ditumbuhkembangkan secara optimal dan terpadu. Karena dengan potensi itulah ia dapat belajar dari lingkungan, alam, dan masyarakat tempat ia tinggal dengan harapan agar menjadi manusia dewasa yang paripurna.

An-Nahlawi menambahkan komentar terhadap penjelasan ayat tersebut bahwa jika potensi pendengaran, penglihatan, dan hati saling berkesinambungan, maka akan lahir ilmu pengetahuan yang dianugerahkan Allah kepada manusia, yang akan membawa manusia kepada kebahagiaan dunia dan akhirat. Ia lebih memfokuskan pada optimalisasi fungsi ketiga potensi tersebut terhadap ilmu pengetahuan dengan menyatakan bahwa pendengaran berfungsi sebagai peme lihara ilmu pengetahuan yang telah ditemukan oleh orang lain, penglihatan memiliki fungsi untuk mengembangkan ilmu pengetahuan dengan menambahkan hasil-hasil penelitian dan pengkajian terhadapnya, serta hati bertugas member sihkan ilmu pengetahuan dari segala noda dan kotorannya. ${ }^{1}$

Pada Al-Qur'an ayat-ayat yang secara langsung dan tidak langsung menunjukkan hubungan Indra, aql, dan kalbu dalam al-Qur'an. Sebagai

\footnotetext{
${ }^{1}$ An-Nahlawi, Pendidikan Islam Di Rumah, Sekolah Dan Masyarakat (Jakarta: Gema Insani Press,
} 1995). 
pengantar terhadap pembahasan yang lebih lanjut, beberapa ayat tersebut akan dibahas secara sekilas berdasarkan keterangan dari beberapa tafsir. tafsir yang digunakan adalah al-Tafsir al-Munir fi al-'Aqidah wa al-Syari'ab aw al-Manhaj karya Wahbah al-Zuhailiy, Tafsir al-Mishbah karya Quraisy Syihab, dan Jämi' al-Bayān fí Ta'wil al-Qur'àn karya Muhammad bin Jarīr al-Thabariy. Alasan penggunaan ketiga tafsir tersebut karena kedua yang pertama tergolong karya yang sistematis dan mudah dipahami terutama bagi generasi sekarang. Sedangkan untuk tafsir yang ketiga, akan diambil darinya beberapa riwayat tentang ayat dan riwayat tentang tafsir dari ayat bersangkutan, karena karya ketiga ini dipandang sebagai karya kuno tafsir bi al-ma'tsür dengan pembahasan cukup luas, yang sampai saat ini masih banyak dipakai

\section{Metode}

Penelitian ini didesain dalam bentuk penelitian kepustakaan atau Library research $^{2}$ yang menggunakan berbagai sumber kepustakaan sebagai sumber data penelitian. Penelitian Kepustakaan atau Library research adalah telaah yang berkaitan kepada pemikiran seorang tokoh yang dalam waktu tertentu, kondisi budaya, masyarakat pada saat itu, beserta dokumen, maka secara metodologis pendekatan yang digunakan adalah pendekatan tafsir. ${ }^{3}$

Metode penelitian yang digunakan adalah metode tafsir al-Qur'an. Sampai saat ini (2001 M) terdapat empat metode tafsir yang popular di kalangan ulama Muslim. Keempat metode itu adalah metode tablili, ijmali, muqaran, dan maudu' $i .{ }^{4}$ Metode tafsir tablili, adalah tafsir yang menyoroti ayatayat al-Qur'an dengan memaparkan segala hal yang berhubungan dengan suatu ayat sesuai dengan urutan bacaan yang terdapat di dalam al-Qur'an Mushaf Usmani. ${ }^{5}$

\section{Potensi Indra, Akal, dan Kalbu dalam al-Qur'an menurut para Mufassir}

a) Ayat yang Secara Langsung Menunjukkan Hubungan akal dan Kalbu

Dari seratus lebih ayat-ayat kalbu dan puluhan ayat-ayat akal, yang menunjukkan secara langsung hubungan akal dan kalbu hanya satu ayat,

\footnotetext{
${ }^{2}$ M. Alfatih Suryadilaga, Metodologi Ilmu Tafsir (Yogyakarta: Terad, 2005).

${ }^{3}$ M. Alfatih Suryadilaga.

${ }^{4}$ Abd al-Hayy al-Farmawi, Al-Bidayah Fi al-Tafsir al-Mawdu'i (al-Qahirah: Dirasah Manhajiyah Mawdu'iyah, 1977).

5 Zahir ibn Awad al-Alma'i, Dirasah Fi Al-Tafsir al-Mawdu'i Li Al-Qur'an al-Karim (Riyad: aljami'ah Ibnu Sa'ud, 1984).
} 
Yakni ayat 46 surat al- $\underline{H} a j j$. Dalam ayat ini akal dan kalbu disebut bersamaan dan beriringan, dimanaakal disebutkan sebagai bentuk kerja dari sosok kalbu.

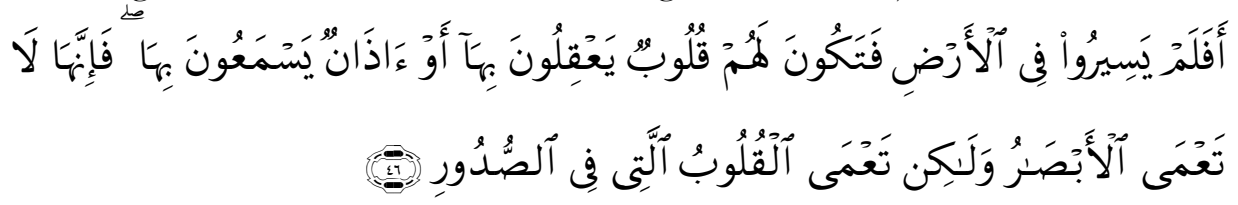

Artinya:"Maka apakah mereka tidak berjalan di muka bumi, lalu mereka mempunyai bati yang dengan itu mereka dapat memahami atau mempunyai telinga yang dengan itu mereka dapat mendengar? Karena sesunggubnya bukanlah mata itu yang buta, tetapi yang buta, ialab hati yang di dalam dada.

Dalam ayat ini, Allah menegur orang-orang kafir dengan memberikan pertanyaan, apakah mereka tidak berjalan dimuka bumi sehingga menyaksikan peninggalan-peninggalan yang pernah dihuni oleh orang-orang sebelumnya yang mendustakan para rasul Allah, lalu dengan demikian mereka mempunyai Kalbu yang dengannya mereka dapat memahami apa yang dilihatnya. Kalaupun bila mata kepala mereka buta, mereka mempunyai telinga yang dengannya mereka dapat mendengar ayat-ayat Allah dan keterangan para rasul-Nya yang telah menyampaikan kepada mereka tuntunan dan nasehat, sehingga dengan demikian mereka dapat merenung dan menarik pelajaran. Mereka itu bukanlah orang-orang buta mata kepala yang membuatnya tidak dapat menemukan kebenaran. Tetapi yang menjadikan mereka tidak dapat menarik pelajaran dan menemukan kebenaran adalah kebutaan Kalbu yang ada di dalam dada.

Al-Thabariy meriwayatkan, bahwa dhomì pada " fa innahā là ta'mä" dalam qira'ah 'Abdullāh dibaca "fa innabu là ta'mä". Lebih lanjut diungkapkan al-Thabriy, disebutnya " $f \grave{\imath}$ al-shudūr" dalam ayat ini adalah bentuk taukid dari Kalbu yang pada dasarnya memang berada dalam shadr (dada). ${ }^{6}$

a. Ayat-ayat lain yang Tidak Secara Langsung Menunjukkan Hubungan akaldan Kalbu

Dalam al-Qur'an ada beberapa ayat yang secara tidak langsung menunjukkan hubungan akaldan Kalbu. Ayat-ayat itu di antaranya adalah: QS. al-An'ām (6): 25, QS. al-A'räf (7): 179, QS. al-Tawbah (9): 87, 93, 127, QS. al-Isrā' (17): 46, QS. al-Kahfi (18): 28, 57, QS. al- $\underline{H}$ ajj (22): 46, al-Qur'an

\footnotetext{
${ }^{6}$ Abū Ja'far Muhammad bin Jarīr al-Thabariy, Jāmi' al-Bayān F̌̄ Ta'mīl al-Qừ'ān (Beirut: Dār alKutub al-'Amaliyyah, 1992).
} 
surat. Mubammad (47): 24, al-Qur'an surat Qäf (50): 37, dan al-Qur'an surat alMunäfiqün (63): 3. Dalam ayat-ayat ituakaldisebutkan dengan kata-kata lain yang sungguhpun berbeda, tetapi menunjukkan aktifitas yang identik dengan 'aql, yakni memahami (faqiba), mengetahui ('alima), mengingat (drakara), memper hatikan (tadabbara) dan lupa (ghafala). Untuk memperjelasnya, dalam hal ini akan dipaparkan empat ayat sebagai sampel.

1) al-Qur'an surat al-Anām (6): 25
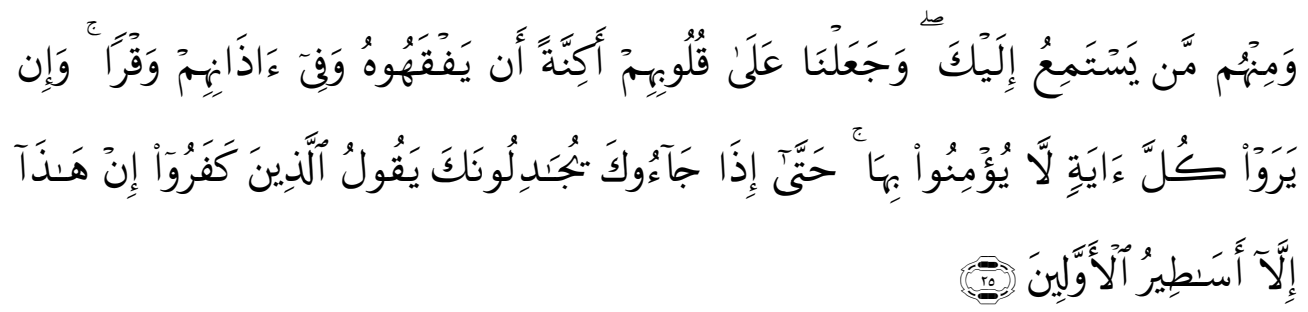

Artinya: "Dan di antara mereka ada orang yang mendengarkan (bacaan)mu, padahal Kami telah meletakean tutupan di atas hati mereka (sehingga mereka tidak) memahaminya dan (Kami letakkan) sumbatan di telinganya. dan jikapun mereka melihat segala tanda (kebenaran), mereka tetap tidak man beriman kepadanya. sehingga apabila mereka datang kepadamu untuk membantabmu, orang-orang kafir itu berkata: "Al-Qur'an Ini tidak lain hanyalah dongengan orang-orang dabulu."

Dalam asbāb al-nuथ̄ul tidak ditemui sebab-sebab jelas yang menjadi lantaran turunnya ayat ini. Ayat ini masih termasuk dari golongan ayat-ayat makkiyah, di mana Islam masih baru berkembang dan dalam situasi kaotis yang belum mapan. Dilihat dari segi munāsabah, ayat ini mempunyai kaitan erat dengan ayat-ayat terdahulu, dimana kalau ayat sebelumnya memaparkan kebohongan kaum musyrikin ketika ditanya di akhirat, dalam ayat ini ditunjukkan betapa mereka di dunia juga mendustakan kebenaran ketika sampai pada mereka.

Di antara orang-orang kafir ada yang tidak secara langsung berpaling. Mereka dengan sungguh-sungguh dan sengaja mendengarkan apa yang dikatakan Nabi SAW., tetapi Allah telah meletakkan penutup atas hati mereka karena pada dasarnya mereka tidak mau mengerti. Tujuan mereka mendengarkan adalah untuk mencari dalih melemahkan al-Qur'an, sehingga 
dengan demikian tidak akan mendapatkan pemahaman yang bermanfaat. Selain itu, di telinga mereka ada "sumbatan" yang membuat mereka tidak dapat mendengar dengan pendengaran yang dapat merasuk ke dalam jiwa mereka. Jika mereka melihat terhadap ayat-ayat Allah, baik dengan mata kepala maupun mata Kalbu, mereka tidak akan mau beriman kepadanya, karena segala potensi yang Allah anugerahkan telah mereka abaikan. Demikianlah keadaan mereka, sehingga mencapai tingkat yang menjadikan apabila mereka datang kepadamu, baik secara langsung atau tidak, mereka berkata bahwa al-Qur'an tidak lain kecuali dongeng-dongeng orang terdahulu, yang diceritakan sebagai hiburan oleh dan bagi orang-orang yang iseng. ${ }^{7}$

Diriwayatkan dari Ashbāth dari Sadyi, "ammā akinnah fa al-ghithä" akanna quībabum" ("akinnah adalah tutup yang menutup Kalbu mereka"). Dan diriwayatkan dari Qatādah, bahwa yang dimaksud dengan "wa ja'alnā 'alā qubübibim akinnah wa fi ädränibim waqrä’ adalah, mereka mendengar dengan telinganya, tetapi tidak berfaedah sedikit pun. Mereka seperti hewan yang mendengar adanya seruan, tetapi tidak mengetahui apa yang dikatakan. ${ }^{8}$

2) al-Qur'an surat al-A'räf (7): 179

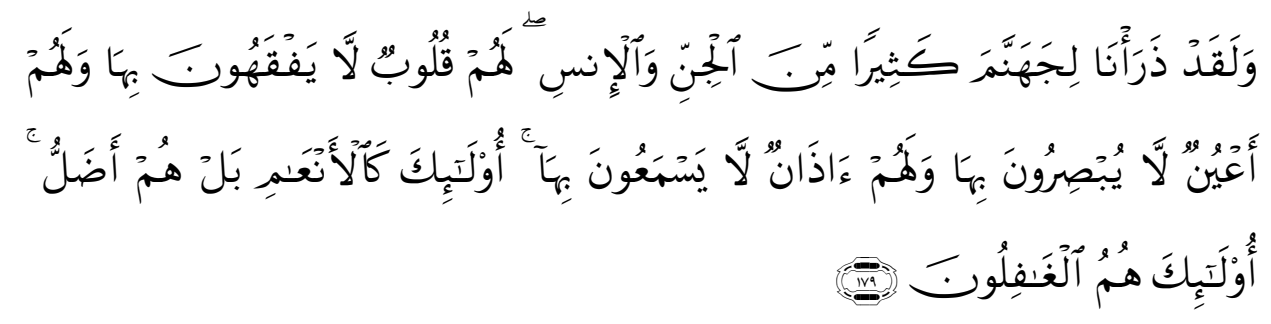

Artinya: "Dan Sesunggubnya kami jadikan untuke (isi neraka Jahannam) kebanyakan dari jin dan manusia, mereka mempunyai bati, tetapi tidak. dipergunakannya untuk memahami (ayat-ayat Allab) dan mereka mempunyai mata (tetapi) tidak dipergunakannya untuk. melihat (tandatanda kekuasaan Allah), dan mereka mempunyai telinga (tetapi) tidak dipergunakannya untuk mendengar (ayat-ayat Allah). mereka itu sebagai binatang ternak, babkan mereka lebih sesat lagi. mereka Itulah orang-orang yang lalai."

\footnotetext{
${ }^{7}$ Muhammad Quraisy Syihab, Tafsir Al-Mishbab: Pesan, Kesan Dan Keserasian al- Quran, vol. 11 (Jakarta: Lentera Hati, 2005).

${ }^{8}$ Abū Ja'far Muhammad bin Jarīr al-Thabariy, Jāmi' al-Bayān F̄̄ Ta'wül al-Qur'ān.
} 
Dalam asbäb al-nuð̄ūl tidak ditemui sebab-sebab jelas yang menjadi lantaran turunnya ayat ini. Ayat ini masih termasuk dari golongan ayat-ayat makkiyah, di mana keadaan Islam masih belum mapan. Dilihat dari sisi munasabah, ayat ini dan satu ayat sebelumnya dimasukkan oleh Wahbah alZuhailiy dalam satu tema "Sebab-sebab hidayah dan kesesatan". Setelah membahas ayat-ayat yang mempersamakan orang-orang yang berpaling dari agama dengan anjing, maka dalam ayat ini diterangkan sebab-sebab kesesatan mereka.'

Selain menjadi penjelasan mengapa seseorang tidak mendapat petunjuk dan mengapa pula disesatkan Allah, ayat ini juga befungsi sebagai ancaman kepada mereka yang mengabaikan tuntunan pengeta huannya. Kalbu, mata dan telinga orang-orang yang memilih kesesatan dipersamakan dengan binatang, karena binatang tidak bisa menganalogikan apa yang ia dengar dan apa yang ia lihat dengan sesuatu yang lain. Lebih dari itu, manusia yang diberi anugerah akaldianggap lebih buruk dari binatang, sebab dengan instinknya binatang akan selalu mencari kebaikan dan menghindari bahaya. Sementara manusia yang sesat justru menolak kebaikan dan kebenaran, malahan mereka mengarah kepada bahaya yang tiada taranya. Setelah kematian mereka akan kekal di api neraka, berbeda dengan binatang yang punah dengan kematiannya. ${ }^{10}$

Kata al-ghäfilīn terambil dari kata ghaflah, yakni lalai, tidak mengetahui atau menyadari apa yang seharusnya diketahui dan disadari. Keimanan dan petunjuk Allah sedemikian jelas, apalagi bagi yang berpengetahuan, tetapi bila mereka tidak memanfaatkannya maka mereka bagaikan orang yang tidak mengetahui atau menyadari bahwa mereka memiliki potensi atau alat untuk meraih kebahagiaan. Inilah kelalaian yang tiada taranya.

3) al-Qur'an surat, al-Tawbah (9): 87.

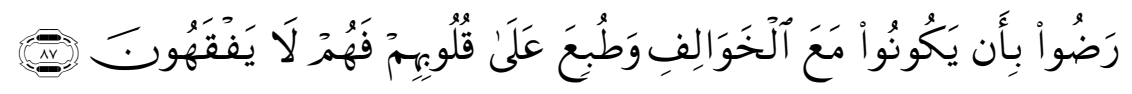

Artinya:"Mereka rela berada bersama orang-orang yang tidak berperang, dan bati mereka Telah dikunci mati Maka mereka tidak mengetahui (kebahagiaan

\footnotetext{
${ }^{9}$ Wahbah al-Zuhailiy, Al-Tafsìr al-Munì Fi al-'Aqìdah Wa al-Syarìah Aw al-Manhaj (Beirut: Dār al-Fikr al-Mu'āshir, t.th, n.d.).

${ }^{10}$ Muhammad Quraisy Syihab, Tafsir Al-Mishbab: Pesan, Kesan Dan Keserasian al- Quran.
} 
beriman dan berihad)". ${ }^{11}$

Dalam asbäb al-nu₹̄̄l tidak ditemui sebab-sebab jelas yang menjadi lantaran turunnya ayat ini. Ayat ini termasuk dalam golongan ayat-ayat Madāniyah, di mana struktur dan kehidupan kaum muslimin boleh dikatakan sudah mapan. Dilihat dari sisi munāsabah, ayat ini dan satu ayat sebelumnya serta dua ayat sesudahnya dimasukkan oleh Wahbah al-Zuhailiy dalam satu tema, "Permintaan izin para tokoh kaum munafik untuk tidak mengikuti jihad". ${ }^{12}$ Quraisy Syihab mengatakan ada hubungan yang erat antara ayat ini dengan ayat-ayat sebelumnya. Ayat-ayat sebelumnya menerangkan larangan mengagumi harta dan anak-anak kamu munafik, antara lain karena mereka tidak menggunakannya untuk kebaikan, maka di sini dijelaskan keburukan mereka yang lain. Keburukan tersebut adalah, apabila diturunkan ayat untuk beriman kepada Allah dan berjihad bersama Rasul-Nya, niscaya mereka menggunakan dalil yang sangat rapuh untuk tidak ikut berjihad. ${ }^{13}$

Dalam Jämi' al-Bayān karya al-Thabariy disebutkan, berdasar apa yang diriwayatkan dari Ibn 'Abbas, Dhahak dan Qatādah al-Khawālif adalah al-nisä' (para wanita). ${ }^{14}$ Ayat di atas, menunjukkan keberadaan mereka bersama para wanita adalah tanda dari ketakutan, kebejatan jiwa, dan ketiadaan harga diri mereka. Dan selanjutnya Kalbu mereka dikunci mati akibat kemunafikan yang berkesinambungan, maka akhirnya mereka tidak mengetahui kebaikan dan tidak merasakan lezatnya iman dan jihad. ${ }^{15}$

Kata yafqabün, menurut Quraisy Syihab, biasanya digunakan untuk pengetahuan yang mendalam menyangkut hal-hal tersembunyi. Dengan demikian ayat ini menilai orang munafik tidak mengetahui hal-hal yang mendalam. Mereka hanya mengetahui hal-hal yang bersifat lahiriyah dan material. Adapaun yang bersifat spiritual maka mereka tidak dapat menghayati dan merasakannya. Dan di sinilah sumber kesesatan dan kecelakaan mereka. ${ }^{16}$

4) al-Qur'an surat, al-Kahfi (18): 2

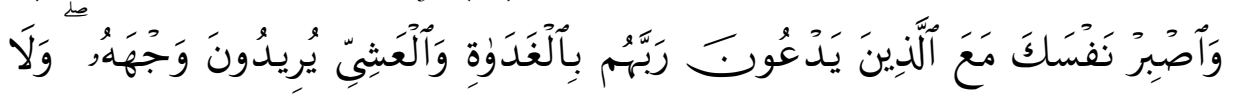

\footnotetext{
${ }^{11}$ Muhammad Quraisy Syihab.

${ }^{12}$ Wahbah al-Zuhailiy, Al-Tafsir al-Munir Fi al-'Aqidah Wa al-Syari'ah Aw al-Manhaj.

${ }^{13}$ Muhammad Quraisy Syihab, Tafsir Al-Mishbab: Pesan, Kesan Dan Keserasian al-Quran.

${ }^{14}$ Abū Ja'far Muhammad bin Jarìr al-Thabariy, Jämi' al-Bayān Fì Ta'wìl al-Qur'ān.

${ }^{15}$ Muhammad Quraisy Syihab, Tafsir Al-Mishbah: Pesan, Kesan Dan Keserasian al-Quran.

${ }^{16}$ Muhammad Quraisy Syihab.
} 


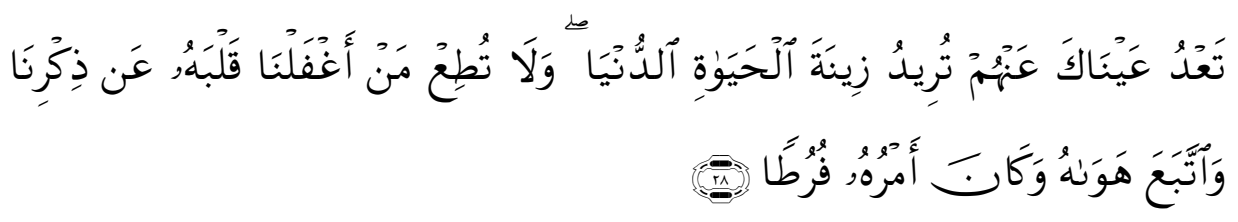

Artinya: "Dan Bersabarlah kamu bersama-sama dengan orang-orang yang menyeru Tuhannya di pagi dan senja hari dengan mengharap keridhaanNya; dan janganlab kedua matamu berpaling dari mereka (karena) mengharapkan perbiasan dunia ini; dan janganlah kamu mengikuti orang yang hatinya Telab kami lalaikan dari mengingati kami, serta menuruti hawa nafsunya dan adalab keadaannya itu melewati batas. ${ }^{17}$

Sebab-sebab turunnya ayat ini seperti diriwayatkan dari Ibn Juraij, bahwa seorang tokoh munafik 'Uyainah bin Hishn berkata kepada Nabi SAW., "Sungguh bau Salmān al-Farisiy yang termasuk golongan orang-orang miskin telah membuatku terganggu, maka buatlah tempat di mana bisa berkumpul tanpa kehadiran mereka, dan buatkan bagi mereka tempat tersendiri di mana mereka biasa berkumpul di sana". Maka diturunkanlah ayat washbir nafsaka alayah. ${ }^{18}$

Surat al-Kahfi ayat 28 ini termasuk dari kategori ayat-ayat Madāniyah. Wahbah al-Zuhailiy mengelompokkan ayat ini dengan satu ayat sebelumnya dan 3 ayat sesudahnya dalam satu tema, "Pengarahan bagi Nabi SAW. dan kaum mukminin untuk membaca al-Qur'an, sabar berkumpul dengan orangorang fakir, dan penjelasan bahwa yang hak berasal dari Allah". Ayat-ayat sebelum ayat ini mengisahkan tentang Ashbäb al-kahfi yang ceritanya masih misteri, karena termasuk hal yang ghaib (tidak hadir/diketahui) bagi masyarakat muslim pada waktu itu. Hal tersebut menunjukkan kemukjizatan al-Qur'an sebagai wahyu dari Allah. Maka Allah memerintahkan Rasulullah SAW. untuk membacanya dan mengumpuli majlis orang-orang fakir yang memperhatikan al-Qur'an. ${ }^{19}$

Salah satu alasan para pemuka kaum musyrikin untuk tidak hadir mendengar wahyu yang disampaikan Nabi SAW. adalah keenganan mereka duduk berdampingan dengan fakir miskin kaum muslimin. Karena itu, Allah memerintah kepada Rasulullah SAW. untuk bersabar memelihara persahabatan dan persaudaraan dengan semua umat muslim, termasuk fakir

\footnotetext{
${ }^{17}$ Zahir ibn Awad al-Alma'i, Dirasah Fi Al-Tafsir al-Mawdu'i Li Al-Qur'an al-Karim.

${ }^{18}$ Abū Ja'far Muhammad bin Jarīr al-Thabariy, Jāmi' al-Bayān Fì Ta'mìl al-Qur'ān.

${ }^{19}$ Wahbah al-Zuhailiy, Al-Tafsir al-Munir Fi al-'Aqidab Wa al-Syari'ah Aw al-Manhaj.
} 
miskin, yang selalu menyeru Tuhannya karena didorong ketaatan dan syukur kepada-Nya sepanjang waktu, baik di waktu pagi maupun senja, dengan harapan mendapat Ridho dari Allah. Janganlah berpaling dari mereka lalu mengarah kepada orang-orang kafir karena kekayaan atau kedudukan sosial mereka, dengan mengharapkan perhiasan dunia. Karena apa yang mereka punya itu hanyalah kenikmatan sementara yang akan segera berakhir dengan kesengsaraan. Dan jangan pula mengikuti orang-orang yang dilalaikan Kalbunya dari mengingat Allah yang disebabkan karena kebejatan diri dan keengganannya mengikuti tuntunan sehingga ia lengah dan selalu tertarik kepada kehidupan duniawi, serta menuruti hawa nafsunya. Mereka itu adalah orang-orang yang sungguh telah melewati batas. ${ }^{20}$

"Man aghfalnā Kalbuah", sesuai dengan riwayat dari Abū al- Kanūd dari Khabāb, meraka adalah 'Uyainah bin Hishn dan Aqra' bin Hābis. ${ }^{21}$ Quraisy Syihab ketika menfasirkan kalimat "Man aghfalnā Kalbuah", mengungkapkan, ini tidak bisa dijadikan alasan untuk mendukung paham fatalisme yang menyatakan manusia tidak memiliki peranan menyangkut kegiatannya. Ayat ini dan semacamnya harus dipahami berkaitan dengan firman-Nya yang antara lain "fa lammà zàghù azäghalläbu Qulübahum" ("Maka ketika mereka berpaling, Allah memalingkan hatinya") ${ }^{22}$

Berdasarkan pejelasan dari ketiga potensi tesebut terlihat dengan jelas memiliki hubungan yang erat, dan saling mendukung satu sama lain, jika satu baian tidak berfungsi dengan baik maka tidak akan menghasilakan suatu respon yang baik pula.

Al-Rāziy membahas permasalahan akal dan Kalbu secara khusus ketika dia menafsirkan al-Qur'an surat, Al-Syu'arā': 193-196. Al-Rāziy menyatakan bahwa jantung (Kalbu)-lah yang pada hakekatnya mendapat khithäb alQuran, karena di sanalah tempat manusia bisa mengetahui dan membedakan sesuatu. Argumen tersebut, menurutnya, didasarkan atas dalil-dalil al-Qur'an, al-Hadits, dan pikiran rasional. Tentang dalil al-Qur'an, Fakhruddīn al-Rāziy mengutarakan beberapa ayat, yang diantaranya adalah al-Qur'an surat, al-A'räf:

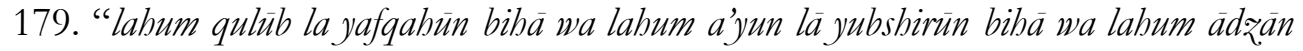
là yasma'ün bihä.'. Ayat tersebut bagi al-Rāziy dengan sendirinya telah menafikan keberadaan ilmu di kepala. Seandainya ada tempat lain bagi ilmu selain di jantung (kalbu), hematnya, maka tujuan yang dikehendaki

\footnotetext{
${ }^{20}$ Abū Ja'far Muhammad bin Jarīr al-Thabariy, Jāmi' al-Bayān Fì Ta'mùl al-Qur'ān.

${ }^{21}$ Abū Ja'far Muhammad bin Jarīr al-Thabariy.

${ }^{22}$ Muhammad Quraisy Syihab, Tafsir Al-Mishbab: Pesan, Kesan Dan Keserasian al- Quran.
} 
ayat tersebut menjadi tidak sempurna. Adapun mata dan telinga tidaklah mempunyai faedah kecuali sebagai penerima kesan yang nantinya dikirim ke Kalbu. Kalbu lah yang akan memberi keputusan apa yang akan dilakukan, karena keberadaannya dalam susunan tubuh manusia layaknya sebagai seorang hakim. Selain al-A'räf: 197, ayat-ayat yang dipakai al-Rāziy untuk memperkuat pendapatnya adalah: al-Qur'an surat, Al-Baqarah 97, al-Qur'an surat, Qäf: 37,

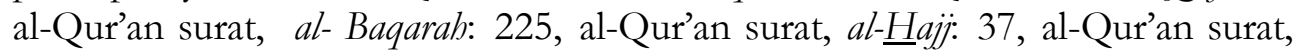
al-Hujurät: 3, al-Qur'an surat, al-'Ádiyāt. 10, al-Qur'an surat, al-Mulk: 10, alQur'an surat, al-Isrä': 36, al-Qur'an surat, al-Mu'min: 19, al-Qur'an surat, alSajdab: 9, al-Qur'an surat, al-Ahqaäf: 26, dan al-Qur'an surat, al-Baqarab: $7 .^{23}$

Sedangkan mengenai dalil rasional yang dipakainya, al-Rāziy memaparkan beberapa alasan dalam membuktikan bahwa kata Kalbu dalam Al-Qur'an menunjukkan arti jantung bukan yang lain. Alasan-alasan tersebut di antaranya sebagai berikut:

a. Apabila jantung mengalami gangguan, tidak berfungsi dan pingsan, maka dipotongnya anggota badan yang lain tidak akan terasa sakit. Dan apabila ia sudah sembuh dan kembali normal, maka ia akan merasakan sakit atas apa yang terjadi pada anggota-anggota badan tersebut. Hal itu menunjukkan bahwa semua organ tubuh tunduk dan mengikuti jantung (kalbu). Oleh karena itulah apabila kalbu (jantung) merasakan bahagia atau susah, maka hal itu akan mempunyai pengaruh terhadap keadaan anggota tubuh yang lain. ${ }^{24}$

b. Jantung (Kalbu) merupakan sumber awal yang membangkitkan gerakan pada anggota tubuh lain. Maka apabila jantung adalah sumber dari pergerakan itu, pastilah pemberi perintah yang mutlak adalah jantung $(\text { Kalbu })^{25}$

c. Disebutnya akaldengan Kalbu (jantung) dalam Al-Qur'an (al-Qur'an surat, Qäf: 37) menunjukkan bahwa jantung merupakan tempat akal. Dan juga dalam al-Qur'an (al-Qur'an surat, al-Baqarah: 10, al-Qur'an surat, al-Nisä': 155, al-Qur'an surat, al-Baqarah: 7, al-Qur'an surat, al-Tawbab: 64, al-Qur'an surat, al-Fatbi: 11, al-Qur'an surat, al-Muthaffifin: 14, al-Qur'an surat, Mubammad: 24, al-Qur'an surat, al-Hajj: 46) sering temui betapa terhadap sifat-sifat kebodohan dan kelalaian, Allah menyandar kannya

\footnotetext{
${ }^{23}$ Imām Muhammad al-Rāziy Fakhr al-Dīn, Tafsìr Al-Fakhr al-Rāãìy al-Musytahir Bi al- Tafsìr alKabir Wa Mafätīh al-Ghaib (Beirut: Dār al-Fikr, 1990).

${ }^{24}$ Imām Muhammad al-Rāziy Fakhr al-Dīn.

${ }^{25}$ Imām Muhammad al-Rāziy Fakhr al-Dīn.
} 
kepada Kalbu. Ini memberikan pengertian bahwa kalbu adalah tempat pengetahuan dan pemahaman sebagaimana juga kebodohan dan kelalaian.

d. Apabila menguji pada diri sendiri, dapat diketahui bahwa pengetahun berada di arah jantung (kalbu). Oleh karena itulah bila berpikir dengan keras secara terus menerus, jantung (kalbu) menjadi sesak dan gelisah, sehingga terasa menyakitkan. Itu semua menunjukkan bahwa tempat akaladalah jantung, dan dengan begitu yang mendapatkan taklif adalah Kalbu karena taklif mensyaratkan adanya akal dan pemahaman.

e. Sesungguhnya jantung adalah bagian tubuh yang paling awal diciptakan dan paling akhir matinya. Selain itu jantung berada di dalam dada yang merupakan pusat tubuh dan berada di tengah-tengah bagian tubuh lainnya. Seperti halnya raja yang membutuhkan para pengawal dan pembantu, ia biasanya berada di tengah wilayah kerajaan, supaya terlindung dari berbagai arah bila datang ancaman atau bencana.

Itulah di antara alasan-alasan rasional yang diungkapkan Fahruddīn al-Rāziy akan keberadaan akal di dalam jantung (Kalbu). Kemudian, setelah memaparkan hal di atas, al-Raziy mengalihkan pembicaraan pada argumen dari orang-orang yang menolak keberadaan akaldi jantung. Bagi kalangan ini akalmanusia berada di otak (dimägh) dengan berbagai alasan, yang di antaranya sebagai berikut:

a. Sesungguhnya indra ( $\underline{\text { bawāsh }}$ ) yang berfungsi sebagai alat untuk merasakan dan mengerti mempunyai koneksi yang mengarah ke otak (dimägh), bukan jantung (Kalbu).

b. Urat-urat syaraf yang merupakan alat untuk mengerakkan anggota badan mempunyai koneksi langsung dari otak, bukan jantung.

c. Sesungguhnya kerusakan yang terjadi di otak akan membuat akalmenjadi kacau.

d. Sesungguhnya akaladalah sesuatu yang sangat mulia, sehingga pantas mendapatkan tempat yang paling mulia. Yang paling atas adalah yang paling mulia, dan itu adalah otak (dimägh) bukannya jantung (Kalbu). Oleh karena itu sudah semestinya bila tempat akal adalah otak (dimägh), bukan jantung (Kalbu).

Setelah memaparkan argumen dari kalangan yang meyakini akabukan berada di jantung (Kalbu), kemudian al-Rāziy berusaha menyanggah argumen tersebut satu persatu dengan beberapa alasan. Pertama, apakah tidak boleh bila dikatakan apa yang ditangkap dan dirasakan oleh indra (bawäsh) dikirimkan ke otak, yang kemudian otak menyampaikan kesan- kesan 
tersebut kepada jantung. Otak adalah alat yang mempunyai hubun gan dekat dengan jantung sedangkan indra adalah alat yang mempunyai hubungan jauh. Indra melayani otak, dan otak melayani jantung. "Kenyataannya", kata al-Raziy, " merasakan bila berpikir tentang sesuatu yang harus dilakukan atau ditinggalkan, maka organ tubuh bergerak pada waktu itu. Dan menemukan bahwa hubungan-hubungan tersebut berasal dari arah jantung (Kalbu), bukan dari otak (dimägh)."

Kedua, tidaklah mustahil seandainya otak mendapat semacam instruksi dari jantung, kemudian otak menggerakkan anggota-anggota tubuh melalui perantaraan urat-urat syaraf yang tumbuh darinya. Ketiga, tidaklah mustahil bila selamatnya otak menjadi syarat sampainya instruksi jantung ke organ-organ tubuh lainnya, karena otak merupakan alat yang digunakan jantung untuk menyampaikan instruksi tersebut. Keempat, apabila benar yang dikatakan mereka, ungkap al-Rāziy, maka akalseharusnya berada di tulang tengkorak. Dan bila tidak, berarti pendapat tersebut salah.

Adapun dalam membedakan istilah shadr, fu'àd, Kalbu dan lubb, al- Rāziy berpendapat, shadr adalah tempat Islam (al-Qur'an surat, al-Zumar. 22), Kalbu adalah tempat iman (al-Qur'an surat, al-Hujurät. 7), fu'äd adalah tempat makrifat (QS. al-Najm: 11) dan lubb adalah tempat tauhid (al-Qur'an surat, al$R a^{\prime} d$ : 19). pembahasan. Dan sesuai dengan namanya, banyak kalangan menganggap $b$ tafsir ini mempunyai corak fiqih yang sangat kental. Akan tetapi sungguhpun al-Qurthūbiy bermadzhab Mālikiy namun dalam penafsirannya ia tidak terikat dengan madzhabnya.

Berkaitan dengan permasalahan akaldan Kalbu, al-Qurthūbiy sungguhpun tidak seluas pembahasan al-Rāziy- menuliskan pembahasannya pada penafsiran al-Qur'an surat,. al-Baqarab: 7. Kalbu orang kafir, ungkap alQurthūbiy, dikatakan mempunyai sepuluh sifat dalam al-Qur'an, yakni: ingkar (al-Qur'an surat, al-Nabl: 22), sombong/hamiyyah (al-Qur'an surat, al-Fath: 26), berpaling/inshiräf (al-Qur'an surat, al-Tawbab:127), keras/qasäwah (al-Qur'an surat, al-Zumar: 22), mati/maut (al-Qur'an surat, al-An'äm: 122), tertutup/rayn (al-Qur'an surat, al-Muthaffifin: 14), sakit/maradh (al-Qur'an surat, Mubammad: 29), sempit/dhaiq (al-Qur'an surat, al-An'am: 125), terkunci/thaba' (al-Qur'an surat, al-Munäfiqün: 3), dan terkunci mati/kbatam (al-Qur'an surat, al-Baqarah: 7). ${ }^{26}$ Adapun mengenai pengertian Kalbu, alQurthūbiy mengatakan:

\footnotetext{
${ }^{26}$ Abū 'Abdillāh Muhammad bin Ahmad al-Anshāriy al-Qurthūbiy, Abū 'Abdillāh Mubammad Bin Ahmad al-Anshāriy al-Qurthübiy (Beirut: Dār al-Kutub al-'Amaliyah, 1993).
} 
"Ungkapan tersebut ('alā qulübibim) menunjukkan kelebihan Kalbu (jantung) atas seluruh anggota tubuh lain. Jantung (Kalbu) dimiliki oleh manusia dan hewan lainnya. Dari segala hal yang inti dan mulia adalah kalbunya. Kalbu adalah tempat pikiran. Pada mulanya, kata kalbu merupakan bentuk mashdar dari ungkapan qalabtu al-syai' aqlibubu kalbunya. Ungkapan ini diucapkan bila membalikkan sesuatu pada permulaannya. Ucapan qalabtu al-inā' (aku membalikkan bejana) berarti radadtubu 'alà wajbih (aku membalikkannya pada bagian mukanya). Kemudian istilah tersebut dipakai untuk menamai anggota tubuh yang paling mulia dari hewan. Alasan penggunaannya karena kecepatan getaran-getarannya serta bolak-baliknya getaran-getaran itu padanya."

Setelah menjelaskan pengertian kalbu tersebut di atas, kemudian alQurthūbiy mengutip sebuah syair Arab yang maknanya antara lain, "Kalbu (jantung) dinamai dengan kalbu karena bolak-baliknya. Karena itu, waspa dalah terhadap bolak-balik dan peralihannya". Dalam hadits Nabi Muhammad SAW. Dikatakan, "perumpamaan jantung (Kalbu) bagaikan sehelai bulu yang dibolak-balikkan angin di tanah lapang." (HR. Ibn Mājah dari Abū Musā al-Asy'ariy). Dan karena makna itu, hemat al- Qurthūbiy, Rasulullah SAW. Sering bermunajat dengan doa ini, "alläbumma ya mutsabbit al-qulüb, tsabbit qulübanā 'alà thäatik" ("Wahai Zat yang menstabilkan kalbu, stabilkan Kalbu kami pada ketaatan kepada-Mu."). Bila dalam munajatnya Nabi SAW. mengatakan demikian, padahal beliau memiliki derajat dan kedudukan tinggi di hadapan Allah, maka, hemat al-Qurthūbiy, lebih utama mengucapkannya sebagai upaya meneladaninya.

Al-Qurthūbiy menyatakan, sungguhpun anggota badan mengikuti perintah kalbu walaupun kalbu dalam tubuh seperti penguasa dan raja-, tetapi apa yang diperbuat oleh anggota-anggota badan tersebut akan mempunyai dampak terhadap kalbu. Hal ini disebabkan adanya hubungan antara yang lahir dan yang batin. Al-Qurthūbiy mengutip sebuah hadits yang diriwayat dari Abū Hurairah "Inna al-rajul liyushiba al-dz̧anba fa yaswadda Kalbubu fa in huwa täba shaqala Kalbub" ("Sesungguhnya seseorang yang tertimpa perbuatan dosa, maka hatinya akan menjadi hitam. Kemudian bila ia bertaubat, maka hatinya akan mengkilap lagi'). Menurut alQurthūbiy, dalam al-Qur'an Kalbu kadang disebut dengan kata shadr dan fu'ad. Tetapi kadang kalbu juga diartikan sebagai akalseperti pada alQur'an surat, Qäf: 37. Hal ini terjadi karena dalam pendapat mayoritas ulama Kalbu adalah tempat 'aql, sedangkan fu'àd adalah tempat Kalbu, dan shadr 
adalah tempat fu'àd. Penisbatan orang-orang yang tidak bisa memanfaatkan potensi Kalbu-nya untuk berpikir seperti hewan ternak dalam al-Qur'an surat, al-A'räf: 179, hemat al-Qurthūbiy adalah karena mereka tidak mendapatkan hidayah. Tujuan hidup mereka adalah makan dan minum layaknya binatang, bahkan lebih buruk lagi karena binatang ternak masih bisa melihat apa yang bermanfaat dan berbahaya baginya, dan ia mengikuti apa yang diperintahkan majikannya, tidak seperti orang-orang itu.

Berkenaan dengan masalah di mana tempat 'aql, sungguhpun tanpa menguraikan alasan yang luas, terlihat kecondongan al-Qurthubiy bahwa akaberada dalam Kalbu. Hal ini tampak jelas ketika dia menafsirkan al-Qur'an surat, al- $\underline{H}$ ajj: 46, al-Qurthūbiy mengatakan:

"kata 'aql disandarkan kepada Kalbu karena akabertempat di Kalbu, sebagaimana pendengaran (sam) bertempat di telinga (udzun). Ada yang mengatakan akalbertempat di otak (dimagh) yang diriwayatkan dari Imām Abū Hanīfah, akan tetapi saya tidak melihat kebenaran di sana".

Sedangkan Muhammad Husein al-Thabathabaiiy adalah seorang pakar tafsir Syi'ah yang dikenal sangat moderat. Karya besarnya dalam bidang tafsir al-Qur'an adalah al-Mizan fí Tafsìr al-Qur'än. Sungguhpun tafsir ini adalah produk Syi'ah, namun sering dipakai sebagai rujukan oleh orang-orang Sunni. Dalam penafsirannya al-Thabathaba'iy, dinilai mempu nyai ciri-ciri khas tertentu, yakni adanya nuansa sosiologis, filosofis, dan juga bätbiniy, sungguhpun grand theory dari tafsir ini adalah tetap tafsir al-Qur'an dengan al-Qur'an. ${ }^{27}$

Dalam tafsirnya tersebut, Thabathaba'iy membahas permasalahan Kalbu dalam sebuah bagian khusus, yakni dalam juz II dengan judul "kalàm fì ma'nā al-Kalbu fi al-Qur'ān". Di awal pembahasannya, ia berusaha menjelaskan maksud dari al-Qur'an surat, al-Baqarah: 225, "Allah tidak menghukum atas sumpahmu, karena celotehan (al-laghw), tetapi Allah menghukum disebabkan (sumpahmu) yang disengaja (untuk bersumpah) oleh Kalbu-mu. Dan Allah Maha Pengampun lagi Maha Penyantun”. Terkait dengan kata Kalbu dalam tersebut, Thabathaba'iy mengatakan:

"Makna tesebut termasuk fakta bahwa yang dimaksud dengan Kalbu ialah manusia dalam arti jiwa (nafs) dan roh. Berpikir (ta'aqqul), berefleksi (tafakkur), cinta, marah, takut, dan sejenisnya, seandainya salah satunya dinisbatkan pada Kalbu dengan keyakinan bahwa Kalbu

\footnotetext{
${ }^{27}$ Abu Qasim Razzaki, “Pengantar Kepada Tafsir Al-Mizan,” Yayasan Muthahari, H 1413.
} 
merupakan anggota peng-idrak dalam tubuh menurut keyakinan pada umumnya, seperti penisbatan mendengar pada telinga, melihat pada mata dan mengecap pada lidah, tetapi mengusahakan (kasb) dan berusaha (iktisäb) hanya dapat disandarkan pada manusia saja. Yang sebanding dengan ayat tersebut ialah ayat yang maknanya antara lain, 'maka sesungguhnya ia adalah orang yang berdosa Kalbu-nya', dan ayat yang maknanya '... dan dia datang dengan Kalbu yang bertaubat'. ${ }^{28}$ Pada ayat tersebut dikatakan kalbu yang berdosa dan kalbu yang bertaubat. Kedua predikat tersebut sama dengan kalbu yang sengaja melakukan sesuatu. Predikat-predikat tersebut merupakan kekhasan manusia. Sebab yang berdosa, bertaubat atau sengaja melakukan sesuatu dengan sadar hanyalah manusia. Namun bagaimana pun juga organ jantung (Kalbu) memiliki peranan penting bagi makhluk hidup.

Menurut Thabathaba'iy, perasaan dan peng-idräk-an akan sia-sia dan lenyap dari makhluk hidup karena ketidaksadaran, seperti pingsan, ayan dan lain sebagainya, walaupun gerakan dan denyut jantung (Kalbu) tetap ada. Berbeda halnya jika jantung terputus. Oleh sebab itulah, hemat Thabathabaiy, sumber pertama hidup dari manusia adalah jantung (Kalbu), dan padanya lah roh berada. Dari jantung, roh mengalir keseluruh anggota badan yang hidup. Dan darinya juga mengalir kesan-kesan dan kekhususan rohaniah sebagai persepsi-persepsi (ihsäsät) yang bersifat emosional (wijdāniyah), seperti perasaan, kehendak, cinta, marah, pengharapan, takut, dan sejenisnya. Seluruhnya dimiliki oleh Kalbu karena ia merupakan sesuatu yang halus dan memiliki keterkaitan dengan roh. Akan tetapi hal ini tidak berarti menafikan keberadaan anggota tubuh lain yang juga merupakan hidung untuk bernapas dan lain-lain. Akan tetapi anggota-anggota tersebut, bagi Thabatba'iy, berkedudukan hanya sebagai perangkat dan alat.

Selanjutnya Thabathaba'iy menegaskan bahwa pendapatnya itu didukung oleh fakta ilmiah hasil eksperimen. Ia mengatakan:

"Pemikiran ini, barangkali didukung oleh hasil eksperimen ilmiah bahwa burung yang otaknya dihilangkan masih tetap hidup. Hanya saja, dia kehilangan daya idrak dan tidak merasakan sesuatu pun. Ia bisa bertahan dalam kondisi itu hingga ia mati ketika bahan- bahan makanan persediaan dalam tubuhnya habis dan denyut jantungnya berhenti."

\footnotetext{
${ }^{28}$ Muhammad Husain al-Thabathaba'iy, Al-Mizān Fi Tasfir al-Qur'àn, II (Beirut: Mu'assasah alA’māliy li al-Mathbūah, 1991).
} 
Fakta ilmiah tersebut membuktikan peranan Kalbu, di mana secara fisik, anggota-anggota tubuh yang lain berada di bawah perintahnya. Namun walaupun demikian, hemat Thabathaba'iy, tidak berarti melalaikan peranan otak dan kekhususannya, yaitu fungsi peng-idräk-an. Ia mene gaskan:

"fakta ilmiah tersebut sebaiknya tidak dianggap melalaikan peranan otak dan fungsi khususnya, yaitu kerja peng-idräk-an. Manusia, jika benar-benar ingat mengenai pentingnya sesuatu yang ada di kepala sejak beberapa waktu silam, dan fakta yang dapat jumpai pada hampir semua bangsa dan agama yang bahasanya berbeda-beda, mereka menamai tempat bermulanya hukum dan perintah dengan kepala ( $r{ }^{\prime}$ 's). Selain itu mereka juga membentuk istilah beragam dari kata kepala $(r a ' s)$, seperti kepala (ra's), ketua (ra'ss), kedudukan (ri'asab), permulaan benang (ra's al-khaith), awal masa (ra's al-muddah), awal jarak (ra's almasäfah), awal pembicaraan (ra's al-kaläm), puncak gunung ( $r a$ 's aljabal), dan lain-lain."

Otak (dimägh) yang bertempat di kepala, fungsinya tidak dapat diremehkan. Otak berperan penting bagi manusia. Peng-idräk-an bagi manusia termasuk fungsi hidup utama. Ketiadaannya mendorong manusia pada tindakan-tindakan yang tidak berbeda dengan binatang, yang hidup hanya untuk makan, tidur, seks dan kesenangan-kesenangan jasmaniah tempat dimulainya perbuatan yang bersifat khusus baginya, seperti otak untuk berpikir, mata untuk melihat, telinga untuk mendengar lainnya. Peng-idräkan, dalam pandangan Thabathabaiiy, juga terkadang dinisbatkan pada kalbu, rüb dan nafs (jiwa). Ia mengatakan:

"Itulah, berdasarkan yang tampak, merupakan sebab penyandaran idräk (penangkapan makna, perasaan dan sesuatu yang tak hampa dari adonan peng-idräk-an, seperti cinta, benci, harapan, takut, hemat, hasud, kesucian (iffah), keberanian, dan lain sebagainya pada kalbu. Yang mereka maksud dengan istilah kalbu adalah rüh yang berkaitan dengan badan, atau yang mengalir padanya melalui kalbu (jantung). Mereka menisbatkan peng-idräk-an, perasaan, dan campuran perngidräk-an pada kalbu sebagimana mereka menisbatkannya pada roh dan jiwa (nafs). Dikatakan: 'aku mencintainya, rohku mencintainya, jiwaku mencintainya dan Kalbu- ku mencintainya.' Kemudian kebolehan penggunaan tersebut menjadi tetap sehingga kata kalbu digunakan dan dengannya dimaksudkan jiwa (nafs) dengan penggunaan secara majäriy. Lalu istilah kalbu juga menyeberang pada kata shadr (dada). 
Penyeberangan tersebut dikarenakan shadr menyelubungi kalbu. lalu kata shadr juga digunakan sebagai istilah bagi tempat peng idräk-an dan perbuatan-perbuatan serta sifat-sifat rohani."

Dari pengertian di atas, Thathaba'iy memandang, yang dimaksud dengan istilah kalbu sebagai tempat penisbatan persepsi, perasaan dan lain sebagainya, adalah roh yang mengalir ke seluruh tubuh melalui kalbu (jantung). Penisbatannya pada kalbu merupakan penggunaan majäriy. Barang kali karena inilah, istilah kalbu, rüh dan nafs dalam penggunaan sehari-hari, khususnya dalam wacana tasawuf disejajarkan. Kemudian dalam kesimpang siuran penisbatan idräk pada kalbu (jantung) dan dimägh (otak), Thabathab'iy mengadopsi apa yang disikapi oleh Syaikh Abū 'Ali Ibn Sinā. Ia mengatakan:

"Syaikh Ibn Sinā mentarjih (mencari fakta yang lebih kuat) antara keberadaan idräk bagi Kalbu. Dalam arti bahwa posisi otak bagi Kalbu adalah sebagai alat. Kalbu memiliki daya idräk, sedangkan otak (dimāgh) adalah medianya." 29

Lain halnya dengan Muhammad Syahrūr (1. 1983 M.), pemikir liberal kontrovesional dari Syiria yang dijuluki sebagai "Immanuel Kant"-nya dunia Arab dan "Martin Luther"nya dunia Islam, adalah salah seorang intelektual yang memiliki kesadaran kritis. Pada dasarnya Syahrūr adalah doktor bidang mekanika tanah dan tehnik pondasi lulusan Universitas College Dublin, yang tidak mempunyai track record pendidikan formal keagamaan. Akan tetapi melalui karya-karyanya, ia dengan keras dan tajam mengkritik konservatisme pemikiran Islam dan berusaha mendeskon truksi hegemoni pemikiran klasik yang masih tertanam kuat dalam pengetahuan dan kesadaran umat Islam. Maka sebagai seorang yang tidak diperkirakan masuk dalam lingkaran wacana keagamaan, Syahrūr harus menghadapi penentangan massif dari hampir seluruh ahli yang professional dalam bidang agama. Bahkan sarjana yang menaruh perhatian terhadap perubahan dan pembaharuan, seperti Nashr Hāmid Abū Zaid, mengkritisi kenaifan metodologi Syahrūr.

Dalam bab II karya monumentalnya, al-Kitäb wa al-Qur'ān, Qiräah Mu'áshirah, yang diterjemahkan ke dalam bahasa Indonesia dengan judul Dialektika Kosmos dan Manusia, Dasar-dasar Epistemologi Qurani, Syahrūr berusaha memaknai kembali istilah Kalbu dan akalsebagai bagian dari unsurunsur pengetahuan manusia. Pertama-pertama Syahrūr mengartikan Kalbu

${ }^{29}$ Muhammad Husain al-Thabathaba'iy. 
sebagai sesuatu yang paling murni dan paling istimewa. Oleh karena itulah, kata kalbu yang ada dalam al-Qur'an, bagi Syahrūr, berarti sebagai organ yang paling istimewa dalam tubuh manusia, yang tidak lain adalah otak (dimägh). Berkaitan dengan ini Syahrūr mengatakan:

"Al-Kitäb secara umum menggunakan istilah al-Kalbu untuk organ yang dianggap sebagai sesuatu yang paling istimewa dalam tubuh manusia. Organ ini adalah 'otak' yang merupakan sesuatu yang paling berharga bagi manusia, sehingga disebut sebagai al-Kalbu. Sedangkan alKalbu atau inti dari otak itu sendiri adalah lapisan paling luar yang merupakan bagian yang paling berharga darinya sebagai pusat dari pikiran dan kehendak. Dengan dasar ini maka tidak perlu diherankan mengapa ketika al-Kitāb menyebutkan organ-organ manusia, dua tangan, kaki, kulit, tenggorokan, telinga, mata, lidah, bibir, darah, dan Kalbu, sedangkan otak disebutkan, padahal ia adalah organ yang paling berharga atau paling penting. ${ }^{30}$

Lebih lanjut, Syahrūur menjadikan al-Qur'an surat, al- $\underline{H} a j j: 46$ dan alA'räf: 179 sebagai landasan bahwa Kalbu bukanlah organ yang berfungsi memompa darah sebagaimana diyakini oleh banyak kalangan selama ini. Menurutnya, dalam ayat tersebut disebutkan organ-organ penting manusia sekaligus dengan fungsi-fungsinya, "telinga yang dengannya mereka mendengar", "mata yang dengannya mereka melihat", dan "qulüb yang dengannya mereka berpikir". Baginya, fungsi berpikir jelas-jelas merupakan potensi otak, sebagaimana mendengar dan melihat adalah jelas fungsi dari telinga dan mata. Penyebutan al-Qur'an yang tidak eksplisit terhadap otak disebabkan karena pembicaraan dalam ayat tersebut (al-Qur'an surat, al- A'räf. 179) adalah jin dan manusia. Benar alat berpikir manusia adalah otak, tetapi dalam konteks jin tidak mesti organ tersebut adalah otak, karena jin adalah mahluk ber akal dari jenis yang lain.

Oleh karena itulah organ berpikir disebut dengan Kalbu, organ yang dianggap paling istimewa dan merupakan bagian yang sama-sama dipunyai manusia dan jin. Adapun mengenai permasalahan tempat kalbu, yang oleh alQur'an dikatakan bertempat di shadr (dada), Syahrūr melihat bahwa pengertian shadr tidak harus berarti dada. Ia mengatakan:

"Al-shudūr yang dimaksudkan di sini bukan dada manusia yang di dalamnya ada organ jantung.... Adapun al-shudür dalam firman- Nya,

30 Muhammad Syahrūr, Dialektika Kosmos Dan Manusia, Dasar-Dasar Episte Mologi Qurani (Bandung: Nuansa, 2004). 
'sebenarnya, ia adalah ayat-ayat yang jelas bagi sbudür orang-orang yang diberikan ilmu pengetahuan. Dan tidak ada yang mengingkari ayatayat Kami kecuali orang-orang yang zhalim (QS. al-'Ankabüt. 49), yang dimaksudkan juga adalah manusia yang mempunyai posisi vital di kalangan para ulama, yaitu mereka yang mendalam ilmunya. Al-shudīr di sini adalah orang yang paling menonjol di antara manusia. Ia adalah kepala yang menjadi pusat bagi semua elemen-elemen dalam komunitas manusia".

Untuk memperkuat semua argumen di atas, Syahrūr kemudian mengutip beberapa ayat Al-Qur'an yang kemudian dia jelaskan satu persatu maksud-maksudnya sesuai dengan pemikirannya. Ayat-ayat tersebut di antaranya adalah:

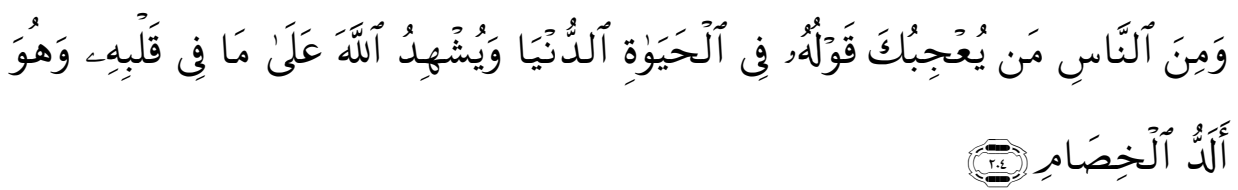

Artinya: "Dan di antara manusia ada orang yang ucapannya tentang kehidupan dunia menarik. Kalbu-mu, dan dipersaksikannya kepada Allab (atas kebenaran) isi Kalbu-nya, padahal ia adalah penantang yang paling keras." 31

Terkait dengan ayat di atas, Syahrūr berpendapat bahwa al-qaul (ucapan/pendapat) adalah adalah aktifitas pikiran, di mana al-kalam ketika berubah menjadi makna di dalam pikiran akan berubah menjadi al-qaul. Ketika manusia mengucapkan sesuatu dan menyembunyikan sesuatu yang lain, maka ia menyembunyikan di dalam otaknya, bukan pada jantung. Apabila yang dimaksudkan dengan al-Kalbu adalah organ jantung pemompa darah, maka hewan-hewan tingkat tinggi seperti kera, juga mempunyai jantung seperti jantung manusia. Akan tetapi, otak kera tidak seperti otak manusia. Itu artinya mereka tidak mempunyai kegiatan atau aktifitas berpikir. Bagi Syahrūr, segala sesuatu yang disebut al-Kalbu dalam al-Kitäb dikaitkan dengan kegiatan-kegiatan berpikir, dan inilah yang membedakan manusia dari hewanhewan yang lain.

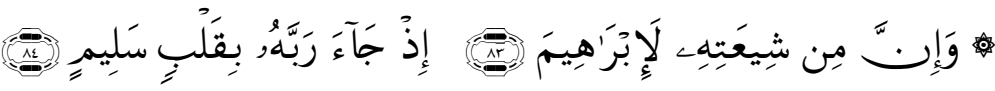

${ }^{31}$ Muhammad Quraisy Syihab, Tafsir Al-Mishbab: Pesan, Kesan Dan Keserasian al- Quran. 
Artinya: "Dan Sesunggubnya Ibrabim benar-benar termasuk golongannya (Nub). (Ingatlah) ketika ia datang kepada Tubannya dengan bati yang suci."

Yang dimaksud dengan al-Kalbu al-salim dalam ayat di atas, bagi Syahrūr, adalah integritas dan kematangan berpikir. Ayat di atas menceri takan Ibrāhīm, yang dikatakan Syahrūr memiliki integritas pemikiran sebagaimana disebutkan dalam al-Qur'an surat, al-Baqarah: 260, "idz qäla ibrabim rabbi ariniy kaifa tubyĩ al-mautā, qāla awalam tu'min, qāla balā waläkin liyathma'inna Kalbuiy". Dalam ayat itu, ungkap Syahrūr, diberikan inti dari metodologi ilmiah yang valid, yang tanpanya tidak mungkin mendapatkan pengetahuan, yaitu metode skeptis untuk sampai pada keyakinan. Selain itu juga metode eksperimentasi ilmiah untuk mengorespon densikan hakikat objektif dengan premis-premis dan kesimpulan-kesimpulan teoritis. Ibrāhīm adalah pemimpin bagi semua manusia, baik yang mukmin atau tidak ("inniy jä'iluka li alnās imāma’'). Oleh karena itu tidak mungkin baginya menjadi pemimpin bagi mereka, kecuali dengan metodologi ilmiah yang benar.

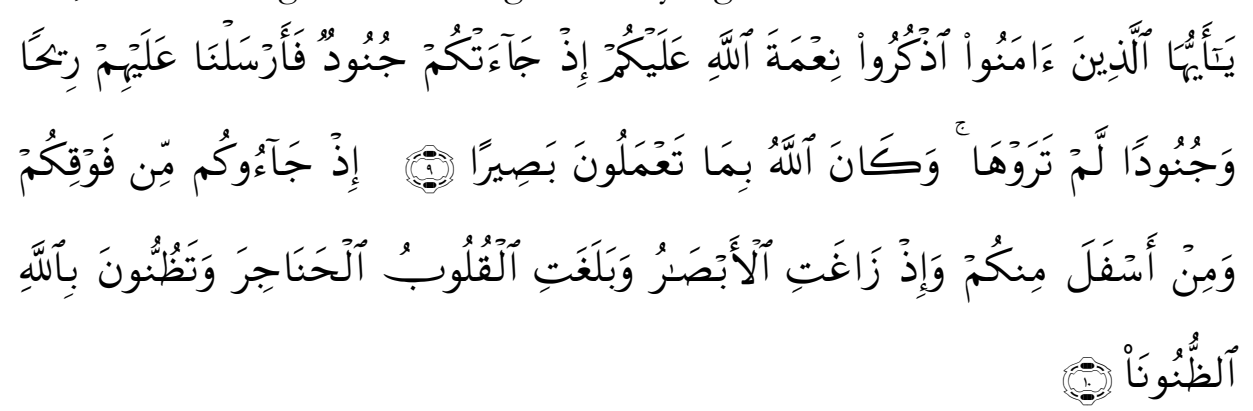

Artinya: "Hai orang-orang yang beriman, ingatlah akan nikmat Allah (yang telah dikurniakan) kepadamu ketika datang kepadamu tentara-tentara, lalu kami kirimkan kepada mereka angin topan dan tentara yang tidak dapat kamu melihatnya. Dan adalah Allah Maha melihat akan apa yang kamu kerjakan. (yaitu) ketika mereka datang kepadamu dari atas dan dari bawahmu, dan ketika tidak tetap lagi penglihatan(mu) dan Kalbu-mu naik menyesak sampai ke tenggorokan dan kamu menyangka terbadap Allah dengan bermacam-macam purbasangka."

Menurut Syahrūr, ketika manusia dihinggapi rasa takut dan mengira bahwa yang dijadikan sandaran sudah tidak mendukungnya, maka dalam kondisi seperti ini yang dijadikan sebagai pegangan adalah Allah. Oleh sebab itulah Allah berfirman, "Dan kalian menyangka kepada Allah dengan bermacam-macam purbasangka." Dalam situasi seperti ini "Kalbu 
naik ke tenggorokan" (wa balaghat al-qulüb al-hanäjir). Maksudnya adalah sebagai berikut: al-banäjir (tenggorok) adalah alat suara, sedangkan al-Kalbu adalah alat berpikir dan rasionalisasi. Ini berarti manusia secara jelas dan nyata mulai menggambarkan keraguan dan keputusasaannya. Demikian juga pada al-Qur'an surat, al-Mu'min: 18, "wa andzirbum yaum al-arifah idz, al-qulūb lad̄̄ al-banājir kaz̧himin". Menurut Syahrūr, pada hari perhitungan, (yaum alarifah) segala sesuatu yang berada di Kalbu (otak) menjadi nampak dalam lidah (ketika kalbu berada di serkerongkongan).

Berdasarkan beberapa ayat di atas, diakhir pembahasan Syahrūur menyimpulkan bahwa ayat-ayat al-Kitäb yang menyebutkan di dalamnya alKalbu, yang dimaksud adalah organ yang paling istimewa dan berharga, yaitu otak yang merupakan organ untuk berpikir. Shahrour mengatakan:

"Inilah kenyataan yang lihat dalam ilmu kedokteran modern, sebab organ jantung (Kalbu) yang merupakan pemompa darah dan bisa dipindahkan dari satu orang kepada orang lain, tanpa harus mempengaruhi kepribadian orang tersebut. Akan tetapi jika otak si Zaid, misalnya, dipindahkan kepada rongga kepala (tengkorak) si Umar, maka Umar akan menjadi Zaid.... mengetahui sekarang bahwa organ pemompa darah dan otak adalah dua organ yang sama-sama istimewa pada diri manusia. Dan otak adalah yang paling berharga karena mati adalah dengan berakhirnya proses otak, bukan dengan terhentinya jantung (Kalbu)."

Selain keempat tokoh tafsir di atas, ada beberapa mufassir lain yang sempat menyinggung kaitan antara akaldan Kalbu. Di antara mufassirmufassir tersebut adalah, al-Tsa'ālabiy (786-876 H./ 1384-1471 M.). Dalam karyanya al-jawäbir al-Hisān fì Tafsìr al-Qur'ān, al-Tsa'ālibiy tidak mengingkari bahwa rusaknya otak akan menyebabkan rusaknya 'Aql, karena baginya ada hubungan antara Kalbu dan dimägh (otak). Tetapi menurutnya tempat akalyang benar adalah Kalbu. Ia berkata, "ayat ini (QS. al- $\underline{H} a j j$ : 46) menunjukkan bahwa tempat akal adalah Kalbu. Dan itulah pendapat yang benar". 32 Demikian halnya dengan Ibn 'Arafah (716-803 H./ 1316-1400 M.). Dalam Tafsir Ibn 'Arafah, tokoh madzhab Malikiy ini juga mengutarakan hal yang sama dalam permasalahan akal dan Kalbu seperti halnya alTsa'ālibiy. Hal serupa juga diungkapkan Abū al-Hasan al-Wāhidiy dalam

\footnotetext{
32 Abd al-Rahmān bin Muhammad bin Makhlūf al-Tsa'ālabiy, Al-Jawāhir al-Hisān Fì Tafsì alQur'ān (Beirut: Mu'asasah al-A'lāmiy li al-Mathbū'āt,t.th, n.d.).
} 


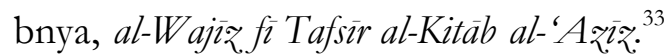

Sementara itu, Haqqiy, dalam Tafsir Haqqiy-nya, sungguhpun tidak secara tegas menyatakan pendapatnya, terlihat kecondongannya bahwa tempat akaladalah di otak (dimägh). Menurutnya, akaldinamakan dengan cahaya rohani yang berfungsi untuk memahami ilmu-ilmu, baik ilmu dharüry maupun ną̧ariy. Tempat akaladalah di otak, karena otak adalah tempat "merasa". Akan tetapi, menurutnya, ada juga yang mengatakan tempatnya adalah di jantung (Kalbu), karena jantung adalah sumber kehidupan dan materi perasa. Ada juga yang mengatakan akaladalah nür (cahaya) yang berada di tubuh anak Adam.

Haqqiy kemudian mengutip sebuah cerita tentang penciptaan Adam. Ketika adam diciptakan, Jibril memberikan tiga pilihan kepada Adam untuk dipilihnya, ilmu ('ilm), malu (bayā)', dan akal('aq). Adam kemudian memilih 'aql. Tetapi ketika Jibril memerintahkan pada 'ilm, dan hayà' untuk kembali ke tempatnya semula mereka tidak mau, dengan alasan ketika di alam arwah mereka bersama-sama, maka mereka tidak bersedia dipisahkan satu dengan yang lainnya. "Oleh karena itulah akal kemudian bertempat di otak, 'ilm bertempat di jantung, dan baya $\bar{a}$ ' bertempat di mata", ungkap Haqqiy.

Mufassir lainnya adalah Muhammad al-Amīn (1325-1393 H./ 1907-1973 M.). Dalam karyanya Adhwa' al-Bayān fi Idhäh al-Qur'ān bi alQur'ān, Muhammad al-Amīn menyatakan bahwa al-Qur'an surat, al- $\underline{H} a j j: 46$ menunjukkan tempat akaladalah di Kalbu (jantung), seperti halnya tempat pendengaran adalah telinga (udzun). Baginya, pendapat kaum filosof yang menganggap tempat akaberada di otak (dimägh) adalah pendapat yang batil.

Demikian pula ia menyalahkan pendapat kalangan yang menyangka bahwa akal tidak mempunyai tempat khusus dalam tubuh, karena akabersifat zamāniy (waktu) bukan makāniy (tempat). Pendapat serupa juga diungkapkan oleh Abū 'Abdillāh Muhammad Ibn Juziy, dalam bnya, al-Tashīl li Ulüm al-Tan₹īl. ${ }^{34}$

Adapun menurut al-Syaukāniy, dalam karyanya Fath al-Qadìr al-Jāmi' bain Faniy al-Riwaȳah, kalimat " $f a$ takēn lahum quhüb ya'qilün bihä" adalah sebab yang mewajibkan menyandarkan aktifitas berpikir kepada Kalbu (jantung).

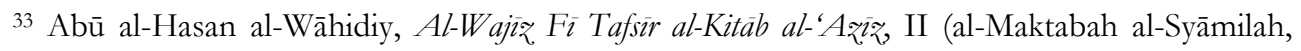
n.d.).

${ }^{34}$ Abū 'Abdillāh Muhammad Ibn Jaziy, Al-Tashīl Li Ulūm al-Tanžll, II (al- Maktabah alSyāmilah, n.d.).
} 
Al-Syaukāniy berkata: "Dikatakan bahwa akalberada di otak (dimāgh), dan tidak ada yang menghalangi hal tersebut. Karena sesungguhnya, Kalbu lah yang mengirimkan pemahaman 'aql, sungguhpun tempatnya berada di luar Kalbu." 35

Sedangkan Rasyīd Ridhā dalam Tafsìr al-Manār mengungkapkan, penggunaan kata kalbu untuk perasaan-perasaan yang bersifat psikis dan maknawi adalah karena kondisi dimana seseorang merasakan sesak atau lega ketika dia merasa takut dan gentar, atau saat dia merasa senang dan gembira. ${ }^{36}$ Oleh karena itu, menurutnya, ketika Nabi SAW. ditanya oleh seorang sahabat tentang kebaikan dan dosa maka beliau bersabda, "Bertan yalah pada kalbu-mu. Kebaikan adalah apa-apa yang membuat tenang jiwa dan kalbu, sedangkan dosa adalah apa-apa yang membuat kotor Kalbu dan membuat bimbang dada (shadr)." Dan setelah itu, hemat Rasyīd Ridhā, penggunaan kata kalbu menjadi meluas. Masyarakat kemudian menggunakan kata kalbu dalam makna pemahaman akal, tetapi itu bukanlah penggambaran dan pembenaran yang mutlak. Keadaan seperti itu tidaklah menafikan tempat akaldi otak (dimägh). "Sesungguhnya penggunaan secara bahasa (lughawiy) tidaklah mengharuskan kecocokannya dengan kenyataan ilmiah", ungkapnya.

\section{Simpulan}

Melalui penelitian ini dapat disimpulkan bahwa:

1. Terlihat dengan jelas memiliki hubungan yang erat, dan saling mendukung satu sama lain, jika satu baian tidak berfungsi dengan baik makatidak akan menghasilakan suatu respon yang baik pula.

2. Potensi Indra, aql, dan Kalbu memiliki hubungan yang kuat, dan tidak terpisahkan. Kedudukan masing-masing potensi dan yang menggerakkan potensi, sehingga menghasilkan aplikasi dari akibat rangsangan yang diterima oleh indra yang kemudian di transfek ke oak dan otak mengirimkan data ke Jantung dan jantung yang nutuskan perkara, sehingga menghasilakan tindakan

\footnotetext{
35 Al-Syaukāniy, Fath Al-Qadìr al-Jämi’ Bain Faniy al-Riwaỹyah W a al-Dirāyah (Beirut: Dār al-Kutub al-'Ilmiyah, 1994).

${ }^{36}$ Muhammad Rasyīd Ridhā, Tafsìr Al-Manār (Beirut: Dār al-Ma'rifah, t.th, n.d.).
} 


\section{Daftar Pustaka}

Abd al-Hayy al-Farmawi. Al-Bidayah Fi al-Tafsir al-Mawdu'i. al-Qahirah: Dirasah Manhajiyah Mawdu'iyah, 1977.

Abd al-Rahmān bin Muhammad bin Makhlūf al-Tsa'ālabiy. Al-Jawāăir al-Hisān Fì Tafsìr al-Qur'ān. Beirut: Mu'asasah al-A 'lāmiy li al-Mathbū'āt,t.th, n.d.

Abū 'Abdillāh Muhammad Ibn Jaziy. Al-Tashìl Li Ulüm al-Tanæৃ̣l. II. alMaktabah al-Syāmilah, n.d.

Abū 'Abdillāh Muhammad bin Ahmad al-Anshāriy al-Qurthūbiy. Abū'Abdillāh Muhammad Bin Ahmad al-Anshäriy al-Qurthübiy. Beirut: Dār al-Kutub al'Amaliyah, 1993.

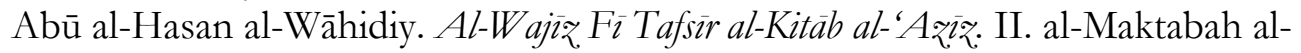
Syāmilah, n.d.

Abū Ja'far Muhammad bin Jarìr al-Thabariy. Jämi' al-Bayān Fì Ta'wìl al-Qur'àn. Beirut: Dār al-Kutub al-'Amaliyyah, 1992.

Abu Qasim Razzaki. "Pengantar Kepada Tafsir Al-Mizan.” Yayasan Muthahari, H 1413.

Al-Syaukāniy. Fath Al-Qadìr al-Jāmi' Bain Faniy al-Rìwāyah Wa al-Dirāyah. Beirut: Dār al-Kutub al-'Tlmiyah, 1994.

An-Nahlawi. Pendidikan Islam Di Rumah, Sekolah Dan Masyarakat. Jakarta: Gema Insani Press, 1995.

Imām Muhammad al-Rāziy Fakhr al-Dīn. Tafsìr Al-Fakhr al-Rāàiy al-Musytahir Bi al- Tafsì al-Kabir Wa Mafätīh al-Ghaib. Beirut: Dār al-Fikr, 1990.

M. Alfatih Suryadilaga. Metodologi Ilmu Tafsir. Yogyakarta: Terad, 2005.

Muhammad Husain al-Thabathaba'iy. Al-Mizān Fi Tasfir al-Qur'ān. II. Beirut:

Mu'assasah al-A'māliy li al-Mathbūah, 1991.

Muhammad Quraisy Syihab. Tafsir Al-Mishbab: Pesan, Kesan Dan Keserasian alQuran. Vol. 11. Jakarta: Lentera Hati, 2005.

Muhammad Rasyīd Ridhā. Tafsìr Al-Manār. Beirut: Dār al-Ma’rifah, t.th, n.d.

Muhammad Syahrūr. Dialektika Kosmos Dan Manusia, Dasar-Dasar Episte Mologi Qurani. Bandung: Nuansa, 2004.

Wahbah al-Zuhailiy. Al-Tafsir al-Munir Fi al-'Aqidah Wa al-Syaríah $A w$ alManhaj. Beirut: Dār al-Fikr al-Mu'āshir, t.th, n.d.

Zahir ibn Awad al-Alma'i. Dirasah Fi Al-Tafsir al-Mawdu'i Li Al-Qur'an al-Karim. Riyad: al-jami'ah Ibnu Sa’ud, 1984. 